\title{
Two Species of Koellikerina Medusae (Cnidaria, Hydrozoa, Anthomedusae) from Japan
}

AUTHOR(S):

Kawamura, Mariko; Kubota, Shin

\section{CITATION:}

Kawamura, Mariko ...[et al]. Two Species of Koellikerina Medusae (Cnidaria, Hydrozoa, Anthomedusae) from Japan. PUBLICATIONS OF THE SETO MARINE BIOLOGICAL LABORATORY 2005, 40(3-4): 121-130

ISSUE DATE:

2005-12-25

URL:

http://hdl.handle.net/2433/176326

RIGHT: 


\title{
Two Species of Koellikerina Medusae (Cnidaria, Hydrozoa, Anthomedusae) from Japan
}

\author{
MARIKo KaWAMURA and SHIN KubOTA
}

\author{
Seto Marine Biological Laboratory, Field Science Education and Research Center, \\ Kyoto University, Shirahama, Nishimuro, Wakayama 649-2211, Japan
}

\begin{abstract}
We fully described two Koellikerina species from shallow waters in Japan with illustrations and photographs. Koellikerina constricta (Menon, 1932), bearing characteristic bell constriction, expands its distribution to Kuchinoerabu Island, Kagoshima Prefecture (northern limit). Koellikerina bouilloni $\mathrm{n}$. $\mathrm{sp}$. is added to eight known species of the genus Koellikerina on the basis of an absence of bell constriction, a colorless body, and the presence of adaxial ocelli, perradial gonads, and a peduncle by examining a specimen from Tanabe Bay, Wakayama Prefecture and 18 specimens formerly collected from Papua New Guinea. Although bell constriction has been criticized as a taxonomic character, we conclude that it is reliable among Koellikerina because all the $K$. bouilloni specimens at variable developmental stages lack bell constriction and are clearly distinguishable from $K$. constricta.
\end{abstract}

Key words: Koellikerina constricta, Koellikerina bouilloni n. sp., hydromedusae, taxonomy, zoogeography, distribution, new species, Kuchinoerabu Island, Tanabe Bay

\section{Introduction}

The genus Koellikerina Kramp, 1939 (Anthomedusae, Bougainvilliidae), which is characterized by eight groups of marginal tentacles, includes 11 medusan nominal species and one unidentified species (Bouillon and Boero, 2000; Miyake et al., 2004; Xu and Huang, 2004). The polypoid stage is known only for K. fasciculata (Péron and Lesueur, 1810) (Bouillon and Boero, 2000). Most species of Koellikerina medusae have been reported from warm, shallow waters in the Atlantic Ocean, the Indian Ocean, and the western coast of the Pacific Ocean (Bouillon, 1980; Kramp, 1959a, 1968; Mayer, 1910; Xu and Zhang, 1978, 1981). Koellikerina maasi (Browne, 1910), however, has been found under the ice from McMurdo Sound, Antarctic (Browne, 1910), and Koellikerina sp. has been found in the deep sea off the west coast of Hokkaido, Japan (Miyake et al., 2004).

We collected two species of Koellikerina from shallow waters in Japan. One specimen of $K$. constricta (Menon, 1932) was collected from Kuchinoerabu Island, in the northern part of the Nansei Islands, during cruises between 1991 and 2004 of the T/RV Toyoshio-maru, Hiroshima University. The specific name, constricta, came from the bell constriction of the holotype (Menon, 1932). Another specimen of the genus Koellikerina that lacked bell constriction was collected from the Pacific coast of Honshu, Japan, during cruises between 1992 and 2005 of the T/RV Janthina III, Seto Marine Biological Laboratory, Kyoto University. After detailed observations, this specimen was found to be new to science and here will be described as a new species. Koellikerina medusae are very rare in Japanese waters (Kubota, 2006, in press); the present records are the first full description of two species of the genus from Japan.

In this study, evaluation of bell constriction as a reliable taxonomic character also is discussed though the bell constriction of $K$. constricta was disregarded as a specific character by Kramp (1965) because it is affected by both medusa development and the state of preservation.

\section{Materials and Methods}

One specimen of Koellikerina constricta from Kuchinoerabu Island, Kagoshima Prefecture, Japan, was collected by snorkeling at the coast of Honmura on May 10, 1991. The medusa was 
swimming just below the sea surface among a swarm of other pelagic plankton, including other medusae, ctenophores, and salps (Kubota, 1993).

Another specimen of Koellikerina was collected from the mouth of Tanabe Bay, the Pacific coast of Honshu, Wakayama Prefecture, Japan, on October 22, 2001, by vertical tow of a plankton net $(0.56$ $\mathrm{m}$ diameter, $0.33 \mathrm{~mm}$ mesh size, NGG54) from $2 \mathrm{~m}$ above the bottom ( $27 \mathrm{~m}$ depth).

Both specimens were fixed in buffered $5 \%$ formalin-seawater within a day of sampling and preserved in the same solution. Drawings were made from both photographs of the living specimens and from preserved specimens using a camera lucida.

\section{Taxonomy}

\section{Family Bougainvilliidae Lütken, 1850 \\ Genus Koellikerina Kramp, 1939 \\ Koellikerina constricta (Menon, 1932)}

(Figs. 1A, 2)

Koellikeria constricta Menon, 1932, 11-12, pl. 2, fig. 11.

Koellikerina constricta: Kramp, 1939: 512; Kramp, 1961: 84; Kramp, 1965: 22;

Kramp, 1968: 37: Xu and Zhang, 1978: 26-27, pl. 1, fig. 2; Xu and Zhang,

1981: 374: Xu and Huang, 2004: 550, Table 3.

Koellikerina sp.: Kubota, 2006 [In Press]: fig. 3, Table 1.

Material examined.

Single mature male medusa (SMBL Cni-10001), $33^{\circ} 27.0^{\prime} \mathrm{N}, 130^{\circ} 10.5^{\prime} \mathrm{E}$, Kuchinoerabu Island, Kagoshima Prefecture, Japan, $1 \mathrm{~m}$ deep, 10 May 1991, collected by S. Kubota. The specimen is deposited in Seto Marine Biological Laboratory, Field Science Education and Research Center, Kyoto University.

Description.

Bell without cnida, pyriform in shape, $6.7 \mathrm{~mm}$ in height, $4.5 \mathrm{~mm}$ in diameter. Distinct bell

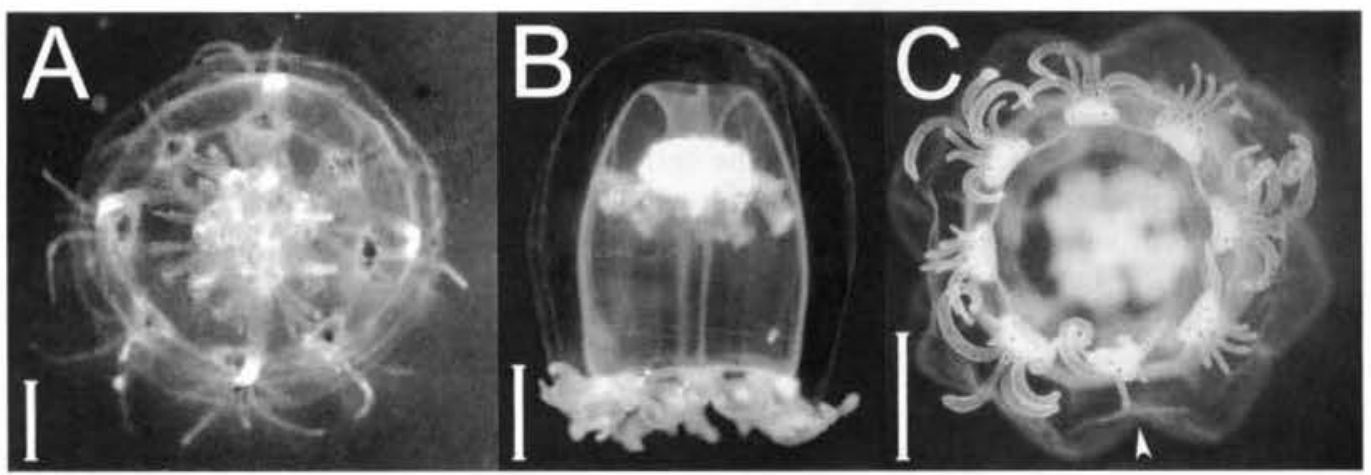

Fig. 1. Photographs of two species of Koellikerina medusae from Japan. A: Mature male medusa of Koellikerina constricta (SMBL Cni-10001), viewed from the bell apex when collected. B: Mature female medusa of Koellikerina bouilloni n. sp. (SMBL Type No, 419), preserved in buffered $5 \%$ formalin-seawater, lateral view. C: Same specimen as (B), oral view. The contracted mesoglea forms V-shaped notches (indicated by arrow) on the bell side one year after collection. Scale bar $=1 \mathrm{~mm}$. 
constriction at about a fifth of its height from top (Fig. 2). Eight clusters of marginal tentacles (Fig. 1A). Seven perradial tentacles and five interradial ones, stemming from each marginal bulb, with single black adaxial ocellus at its base. Marginal bulbs reddish brown in color. Ring canal and four radial canals straight. Manubrium hanging from long and narrow peduncle. Mouth cruciform in shape with four simple oral lips. Each of four perradial oral tentacles branching dichotomously six times, tips of oral tentacles red in color. Each of four gonads V-shaped, formed on perradial sides of stomach, brilliant yellow in color, with four pairs of lateral folds with single median fold (= totally nine lateral folds). Preserved specimens, in buffered 5\% formalin-seawater for 13 years, lost its color in marginal bulbs, tips of oral tentacles, and gonads except for black ocelli.

Geographic Distribution.

Madras, India; Ceylon Island, Sri Lanka; Banda Sea, Indonesia; Guangdong and Fujian, China; Kuchinoerabu Island, Japan.

Remarks.

This is the first full description of $K$. constricta from Japanese waters, and it expands the northern limit of its distribution. Our specimen agreed with the original description from India (Menon, 1932)

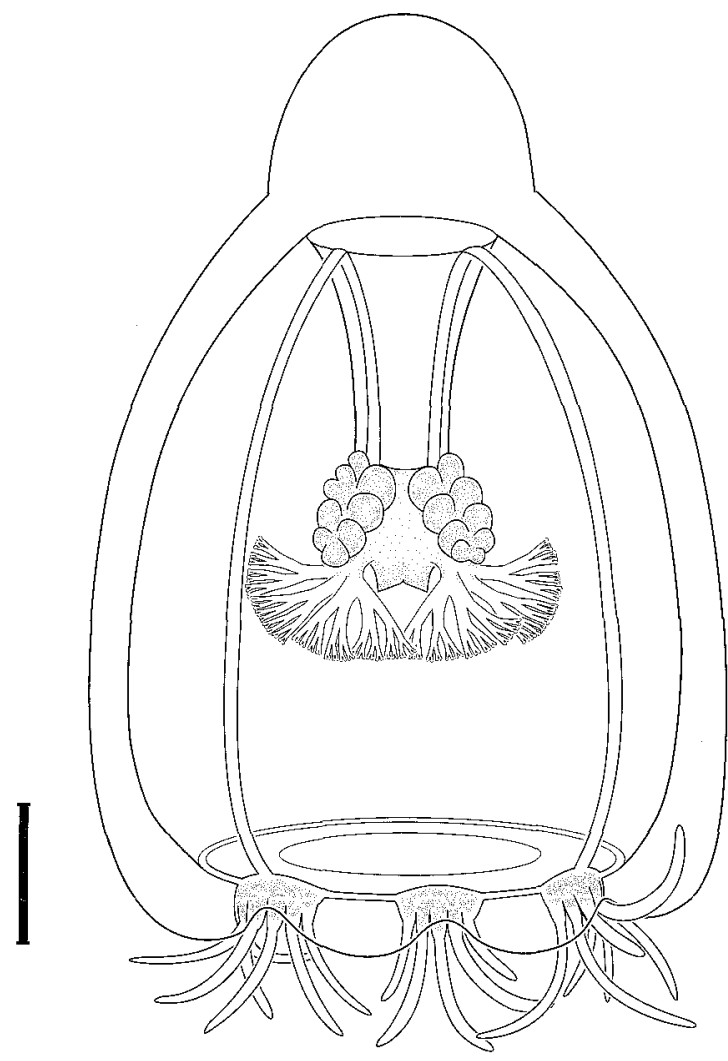

Fig. 2. Mature male medusa of Koellikerina constricta (SMBL Cni-10001), lateral view. Only three clusters of marginal tentacles, two clusters of oral tentacles, two perradial gonads, and two radial canals are shown. Scale bar $=1 \mathrm{~mm}$. 
Table 1. Morphological comparison of a new Koellikerina species with other congeneric medusae.

\begin{tabular}{|c|c|c|c|c|c|c|c|c|}
\hline \multirow[b]{2}{*}{ Species } & \multicolumn{2}{|c|}{ Bell size $(\mathrm{mm})$} & \multicolumn{2}{|c|}{$\begin{array}{l}\text { No. of tentacles/ } \\
\text { marginal bulb }\end{array}$} & \multirow{2}{*}{$\begin{array}{c}\text { No. of } \\
\text { branching of } \\
\text { oral tentacies }\end{array}$} & \multirow{2}{*}{$\begin{array}{l}\text { Projection or } \\
\text { constriction of } \\
\text { bell apex }\end{array}$} & \multirow{2}{*}{ Peduncle } & \multirow{2}{*}{$\begin{array}{c}\text { Ocelli } \\
\text { and its } \\
\text { position }\end{array}$} \\
\hline & height & diameter & perradial & interradial & & & & \\
\hline$K$. bouilloni n. sp. & 4.0 & 3.5 & $7-8$ & $7-8$ & 6 & - & + & + , adaxial \\
\hline $\begin{array}{l}\text { K. bouilloni } \\
(=K . \text { constricta sensu Bouillon } 1980)\end{array}$ & 8 & 7 & 14 & 14 & $7^{1}$ & - & + & + , adaxial \\
\hline \multirow{2}{*}{ K. constricta (Menon, 1932) } & 6.7 & 4.5 & 7 & 5 & 6 & + & + &,+ adaxial \\
\hline & 4-9 & $3-6$ & $5-8$ & $5-8$ & $4-7$ & $t^{2}$ & + &,+ nd \\
\hline K. diforficulata Xu \& Zhang, 1978 & 5 & 4 & 5 & 5 & 2 & - & + & + , abaxial \\
\hline K. elegans (Mayer, 1900) & $3-7$ & 5 & 4 & 3 & $\begin{array}{l}\text { 3, each tip } \\
\text { terminates in } \\
\text { three branche }\end{array}$ & in & + & + , adaxial \\
\hline
\end{tabular}

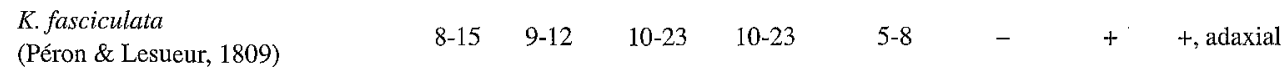

K. maasi (Browne, 1910) $\quad 9-10 \quad 8-9 \quad 5-9 \quad 5-7 \quad 5-8$

\begin{tabular}{lcccccccc} 
K. multicirrata (Kramp, 1928) & $3-6$ & $3-6$ & $9-16$ & $9-16$ & $6-7$ or more & - & - & + , adaxial \\
\hline K. octonemalis (Maas, 1905) & $5-6$ & $4-5$ & $7-9$ & $5-7$ & $5-6$ & - & + & + , adaxial \\
\hline K. ornata Kramp, 1959 & $8-11$ & 8 & $17-19$ & $17-19$ & $5-6$ & + & + & + , adaxial \\
\hline Koellikerina sp. & 21.8 & 18.6 & nd & nd & nd & $-{ }^{3}$ & $++^{3}$ & nd, nd \\
\hline
\end{tabular}

+: present, -: absent, nd: no data

${ }^{1}$ counted from the specimens of $K$. constricta sensu Bouillon 1980

${ }^{2}$ not mentioned in Kramp (1965)

${ }^{3}$ obsevation from Fig. 6 in Miyake et al. (2004) 
Table 1. Continued.

\begin{tabular}{|c|c|c|c|c|c|}
\hline Species & $\begin{array}{l}\text { Position } \\
\text { of gonad }\end{array}$ & $\begin{array}{l}\text { No. of } \\
\text { lateral folds } \\
\text { of gonad } \\
\text { (pairs) }\end{array}$ & Color except for ocelli & $\begin{array}{l}\text { Geographical } \\
\text { distributions }\end{array}$ & $\begin{array}{l}\text { Major references } \\
\text { (No. of individuals examined } \\
\text { in each reference) }\end{array}$ \\
\hline K. bouilloni n. sp. & perradial & 3 & marginal bulb orange & Tanabe Bay, Japan & this study (1) \\
\hline $\begin{array}{l}K . \text { bouilloni } \\
(=K . \text { consiricta sensu Bouillon } 1980)\end{array}$ & perradial & 3 & $\begin{array}{l}\text { proximal part of oral } \\
\text { tentacles orange, tentacle } \\
\text { gold, marginal bulb red, } \\
\text { orange, or yellow }\end{array}$ & Papua New Guinea & $\begin{array}{l}\text { Bouillon, } \\
1980(40)\end{array}$ \\
\hline \multirow{2}{*}{$K$. constricta } & perradial & 4 & $\begin{array}{c}\text { marginal bulb red brown, } \\
\text { tip of oral tentacles red, } \\
\text { gonad yellow }\end{array}$ & $\begin{array}{l}\text { Kuchinoerabu I., } \\
\text { Japan }\end{array}$ & this study (1) \\
\hline & perradial & $3-4$ & marginal bulb brown & $\begin{array}{l}\text { Madras, India; Sri Lanka } \\
\text { Banda Sea, Indonesia; } \\
\text { Guangdong \& } \\
\text { Fujian, China }\end{array}$ & $\begin{array}{c}\text { Menon, } 1932(1) ; \\
\text { Kramp, } 1965(3) ; \\
\text { Xu \& Zhang, } 1978(5) ; \\
\text { Xu \& Huang, 2004 }\end{array}$ \\
\hline K. diforficulata & perradial & $3-4$ & nd & Guangdong, China & $\begin{array}{c}\text { Xu \& Zhang, } 1978 \text { (2); } \\
\text { Xu \& Huang, } 2004\end{array}$ \\
\hline K. elegans & interradial & nd & $\begin{array}{l}\text { oral tentacle pearly pink, } \\
\text { stomach green }\end{array}$ & $\begin{array}{l}\text { Tortugas, Florida; } \\
\text { Trivandrum, India }\end{array}$ & $\begin{array}{l}\text { Mayer, } 1900 \text { (several); } \\
\text { Kramp, } 1961\end{array}$ \\
\hline K. fasciculata & perradial & 5 & $\begin{array}{l}\text { marginal bulb, stomach, } \\
\text { and gonad between } \\
\text { adjacent lateral folds } \\
\text { red to brownish } \\
\text { red, oral tentacle } \\
\text { purple or red }\end{array}$ & $\begin{array}{l}\text { Mediterranean; } \\
\text { Azores; off } \\
\text { Walvis Bay, } \\
\text { Namibia }\end{array}$ & $\begin{array}{l}\text { Péron \& Lesueur, 1810; } \\
\text { Mayer, 1910; } \\
\text { Kramp, } 1948 \text { (1); } \\
\text { Petersen \& Vannucci, } \\
\quad 1960(30) ; \\
\text { Pagès et al., } 1992 \text { (1) }\end{array}$ \\
\hline$K$. maasi & interradial & 0 & stomach red & $\begin{array}{c}\text { Antarctic; } \\
\text { Madagascar; } \\
\text { Papua New Guinea; } \\
\text { New Zealand }\end{array}$ & $\begin{array}{c}\text { Browne, } 1910(24) ; \\
\text { Kramp, } 1965(1) \\
\text { Kramp, } 1968 ; \\
\text { Bouillon et al., } 1.986(2) ; \\
\text { Schuchert, } 1996(2)\end{array}$ \\
\hline K. multicirrata & perradial & $2-3$ & $\begin{array}{l}\text { stomach orange, marginal } \\
\text { bulb yellowish-grey } \\
\text { (in alcohol) }\end{array}$ & $\begin{array}{l}\text { tropical Indian Ocean; } \\
\text { Malay Archipelago; } \\
\text { Guangdong, China }\end{array}$ & $\begin{array}{l}\text { Kramp, } 1928 \text { (1); } \\
\text { Kramp, } 1965 \text { (12); } \\
\text { Xu \& Zhang, 1981 }\end{array}$ \\
\hline$K$. octonemalis & interradial & 0 & $\begin{array}{l}\text { marginal bulb red, stomach } \\
\text { reddish brown, eggs appear } \\
\text { as flecks of yellow }\end{array}$ & $\begin{array}{l}\text { Malay Archipelago; } \\
\text { Guangdong, China }\end{array}$ & $\begin{array}{c}\text { Maas, } 1905(2) ; \\
\text { Xu \& Zhang, } 1981(1)\end{array}$ \\
\hline K. ornata & perradial & $4-5$ & $\begin{array}{l}\text { conical apical projection } \\
\text { with a orange patch, young } \\
\text { tentacle pigmented orange }\end{array}$ & $\begin{array}{c}\text { Sri Lanka; } \\
\text { Papua New Guinea }\end{array}$ & $\begin{array}{l}\text { Kramp, } 1959 \mathrm{~b}(1) \\
\text { Bouillon, } 1980(9)\end{array}$ \\
\hline Koellikerina sp. & perradial $^{3}$ & $>5^{3}$ & oral tentacle red $^{3}$ & off Hokkaido, Japan & Miyake et al., 2004 \\
\hline
\end{tabular}


and the redescription from China (Xu and Zhang, 1978; Xu and Huang, 2004) in bell constriction, the presence of a peduncle, and the perradial gonads (Table 1). Koellikerina ornata Kramp, 1959 also has all these characters, however, it has a larger bell, more tentacles, and orange-colored tip of apical projection and young tentacles (Kramp, 1959b). Kramp (1959b) mentioned that this orange color remained distinct after eight years of storage in formalin and distinguishes $K$. ornata from $K$. constricta. We also examined one K. ornata specimen collected in 1976 and preserved in formalin (IG. 27838 from Laing, Papua New Guinea, Royal Belgian Institute of Natural Sciences); the specimen was $9.0 \mathrm{~mm}$ in bell height and 14-15 in the number of tentacles, and the orange-color remained in its young tentacles.

\section{Koellikerina bouilloni $\mathrm{n}$. sp.}

(Figs. 1B-C, 3A-C)

Koellikerina constricta: Bouillon, 1980: 311-313, fig. 2.

Koellikerina sp.: Kubota, 2003: 31.

Material examined.

Holotype (SMBL Type No, 419), Tanabe Bay, Wakayama, Japan, $27 \mathrm{~m}$ deep, 33 $42.2^{\prime} \mathrm{N}$, $135^{\circ} 21.5^{\prime} \mathrm{E}$, vertical tow, 22 October 2001 , collected by M. Kawamura. The type specimen was deposited in Seto Marine Biological Laboratory, Field Science Education and Research Center, Kyoto University; 14 specimens (IG. 27838), Laing Island, Papua New Guinea, 4⒑5'S, 144 ${ }^{\circ} 52.8^{\prime} \mathrm{E}, 1977$, 1987, collected by J. Bouillon; Four specimens (IG. 27838), Papua New Guinea, 1989, collected by J. Bouillon.

Description.

Holotype mature female medusa. Bell, shallowly rounded apex without cnida, $4.0 \mathrm{~mm}$ in height, $3.5 \mathrm{~mm}$ in diameter (Figs. 1B, 3A). Eight clusters of marginal tentacles (Fig. 1C). Seven or eight tentacles, stemming from each marginal bulb, with single black adaxial ocellus at its base (Fig. 3B). Marginal bulbs triangular (Fig. 1C), orange in color. Ring canal and four radial canals straight. Manubrium hanging from short and wide peduncle. Mouth cruciform in shape with simple oral lips. Each of four perradial oral tentacles branching dichotomously six times from short basal stalk. Each of four gonads horseshoe-shaped, formed on perradial sides of stomach (Fig. 3C), with three pairs of lateral folds without median fold (= totally six lateral folds). Entire body colorless except for black ocelli and orange marginal bulbs. Color of marginal bulbs disappearing after a few years of storage in formalin.

Present species reaching double bell size and twice number of tentacles than holotype (Table 1). Minimal mature specimen with eggs, $2 \mathrm{~mm}$ in bell height (Table 2). Three specimens of same size (4.0-5.0 $\mathrm{mm}$ bell height) as holotype bearing 5-9 tentacles per marginal bulb, 5-7 branching oral tentacles, 1-3 pairs of laterally folded gonads, agreeing with holotype.

Etymology.

The specific name honors Dr. J. Bouillon, who first described this species from Papua New Guinea.

Geographic Distribution.

Laing Island, Papua New Guinea; Tanabe Bay, the Pacific coast of Honshu, Japan (the type locality).

Remarks.

Bouillon (1980) described " $K$. constricta" based on 40 specimens from Papua New Guinea 
without bell constriction. He did not consider bell constriction an important character, in agreement with the conclusion by Kramp (1965), who pointed out that "Some of the structures which have been used as distinguishing characters are variable, and some may depend on the stage of development of the specimens. The state of contraction in preserved specimens should also be considered; this mainly applies to the presence or absence or degree of development of a gelatinous apical projection," and that "The specific name constricta alludes to a characteristic constriction of the umbrella of the type specimen about $1 / 3$ of its height from the top; similar constrictions may, however, appear in many different medusae and no specific signification can be ascribed to them." However, the specimens examined by Bouillon (1980), like our specimen, were relatively large and in good condition, without considerable contraction. Moreover, 18 specimens collected by Bouillon from 1977 to 1989 , examined in the present study, did not show any constriction (Table 2). Bell constriction requires a thickened mesoglea of the bell apex but the mesoglea of $K$. bouilloni is too thin to form a constriction.

In 11 congeneric nominal species of the genus Koellikerina (Bouillon and Boero, 2000, Xu and

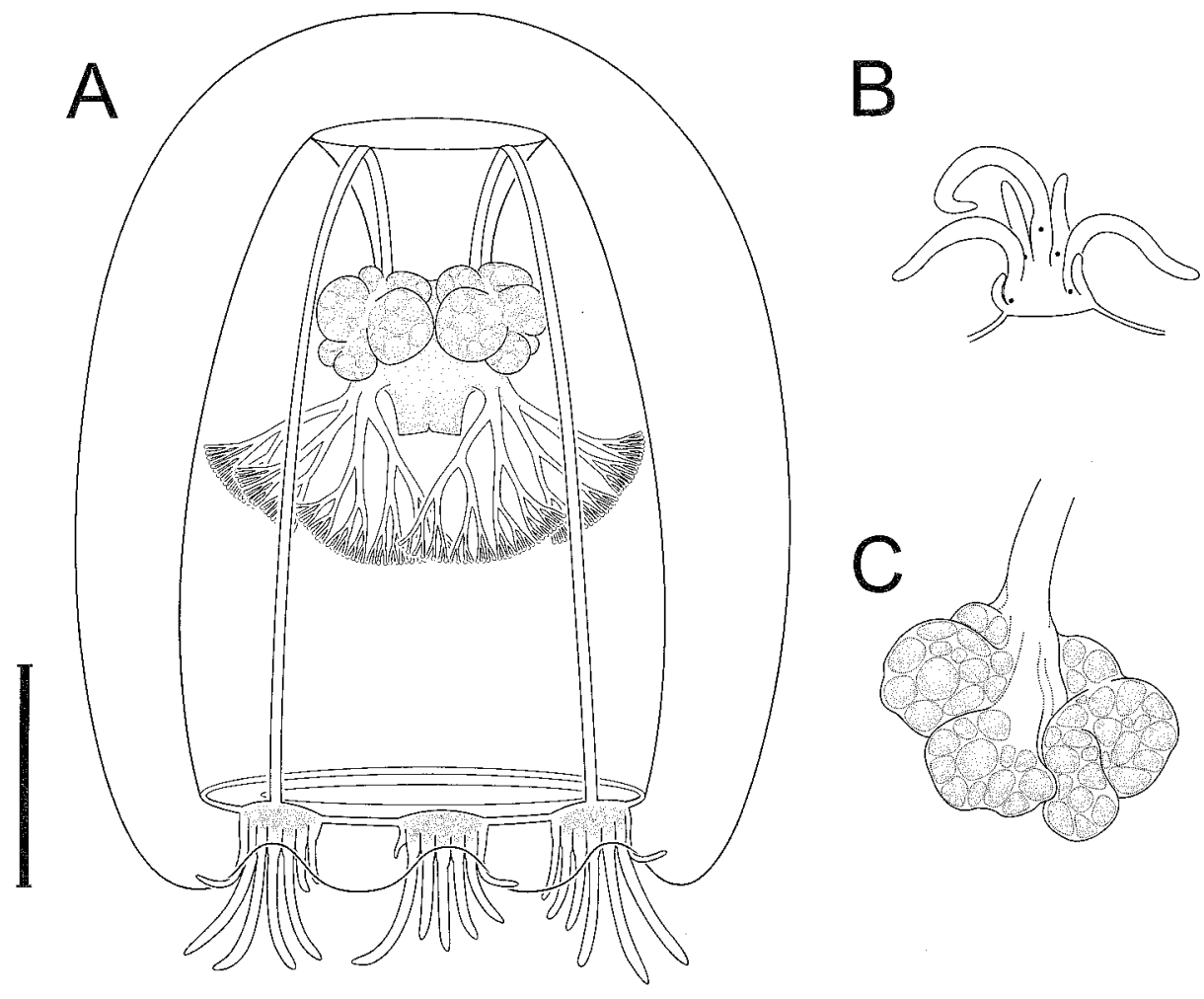

Fig. 3. Mature female medusa of Koellikerina bouilloni n. sp. (SMBL Type No., 419). A: Lateral view; $\mathrm{B}$ : Oral view showing a cluster of marginal tentacles, five large tentacles with an adaxial ocellus, and two young tentacles without an ocellus; $C$ : Lateral view showing a gonad with three pairs of lateral folds containing eggs. Scale bar $=1 \mathrm{~mm}$ for (A) and (B), $0.5 \mathrm{~mm}$ for (C). Only three clusters of marginal tentacles, two clusters of oral tentacles, two perradial gonads, and two radial canals are shown. 
Table 2. Variation of characters among 18 specimens of Koellikerina bouilloni $\mathrm{n}$. sp. from Papua New Guinea

\begin{tabular}{|c|c|c|c|c|c|c|c|}
\hline \multicolumn{2}{|c|}{$\begin{array}{l}\text { Bell size }(\mathrm{mm}) \\
\text { height diameter }\end{array}$} & \multirow{2}{*}{$\begin{array}{c}\text { No. of } \\
\text { tentacles/ } \\
\text { perradial } \\
\text { marginal bulb }\end{array}$} & \multirow{2}{*}{$\begin{array}{c}\begin{array}{c}\text { No. of } \\
\text { branching of } \\
\text { oral tentacles }\end{array} \\
4\end{array}$} & \multirow{2}{*}{$\begin{array}{c}\text { Projection or } \\
\text { constriction of } \\
\text { bell apex } \\
(-: \text { absent }) \\
-\end{array}$} & \multirow{2}{*}{$\begin{array}{c}\text { Sex } \\
\text { (m: male; } \\
\text { f: female) } \\
?\end{array}$} & \multirow{2}{*}{$\begin{array}{l}\begin{array}{l}\text { No. of lateral } \\
\text { folds of gonad } \\
\text { (pairs) }\end{array} \\
1\end{array}$} & \multirow{2}{*}{$\begin{array}{c}\begin{array}{c}\text { Sampling } \\
\text { year }\end{array} \\
1989\end{array}$} \\
\hline 1.8 & 1.8 & & & & & & \\
\hline 2.0 & 2.0 & 3 & 4 & - & $?$ & 1 & 1987 \\
\hline 2.0 & 2.0 & 3 & 4 & - & $?$ & 1 & 1989 \\
\hline 2.0 & 2.0 & 5 & 4 & - & $?$ & 2 & 1977 \\
\hline 2.0 & 2.0 & 5 & 5 & - & $?$ & 1 & 1977 \\
\hline 2.0 & 3.0 & 5 & 5 & - & $\mathrm{f}$ & 1 & 1987 \\
\hline 2.5 & 2.5 & 3 & 5 & - & $?$ & 1 & 1977 \\
\hline 3.0 & 3.0 & 5 & broken & - & $\mathrm{m}$ & 3 & 1987 \\
\hline 3.0 & 3.0 & 5 & 5 & - & $?$ & 1 & 1987 \\
\hline 4.0 & 3.0 & 5 & 5 & - & $?$ & 1 & 1989 \\
\hline 4.0 & 4.5 & 5 & 6 & - & $?$ & 2 & 1977 \\
\hline 5.0 & 5.0 & 9 & 7 & - & f & 3 & 1987 \\
\hline 5.5 & 5.5 & 7 & 7 & - & f & 3 & 1977 \\
\hline 5.5 & 6.0 & 7 & 6 & - & $\mathrm{m}$ & 4 & 1989 \\
\hline 6.0 & 6.0 & 7 & 6 & - & $\mathrm{m}$ & 4 & 1987 \\
\hline 6.0 & 6.5 & 10 & 6 & - & $?$ & 2 & 1987 \\
\hline 7.0 & 7.0 & 13 & 7 & - & $\mathrm{f}$ & 4 & 1987 \\
\hline 8.5 & 7.0 & 13 & 7 & - & f & 4 & 1987 \\
\hline
\end{tabular}

Huang, 2004), K. heteronemalis Xu, Huang and Chen, 1991, K. taiwanensis Xu, Huang and Chen, 1991, and K. staurogaster Xu and Huang, 2004 (based on one young medusa) are treated here as insufficiently described species and perhaps one of the known species of Koellikerina as Bouillon and Boero (2000) pointed out. Compared to eight other congeneric nominal species (Bouillon and Boero, 2000), the present specimen of Koellikerina bouilloni $\mathrm{n}$. sp. is similar to K. fasciculata from the Mediterranean Sea in sharing an absence of bell constriction and the presence of adaxial ocelli, perradial gonads, and a peduncle (Table 1). However, $K$. fasciculata is different from $K$. bouilloni in that it has a larger body size, more tentacles, and red colored gonads between adjacent lateral folds, oral tentacles, and marginal bulbs, as well as a stomach (Mayer, 1910; Péron and Lesueur, 1810; Petersen and Vannucci, 1960). In K. fasciculata, a brick-red color is apparent on the manubrium of newly liberated medusae; the color expands to the oral tentacles, gonads, and the stomach as the medusa develops (Petersen and Vannucci, 1960). This red color remains distinct after 40 years of storage in formalin-seawater (IG. 27838 from Naples, Italy, Royal Belgian Institute of Natural Sciences), and is a stable character for $K$. fasciculata. In common, other medusae is not stained such a deep red as $K$. fasciculata even though they feed Artemia nauplii, which had been used as foods by Petersen and Vannucci (1960). Moreover, any coloring due to food consumption usually disappears after digestion.

Three medusae of Koellikerina sp. were recently observed from the south slope of Shiribeshi Seamount off the west coast of Hokkaido, Japan, at depths of $627-685 \mathrm{~m}\left(<1^{\circ} \mathrm{C}\right)$. They possessed red oral tentacles (Fig. 6 in Miyake et al., 2004), much higher bell, and more lateral folds on the gonads, than $K$. bouilloni (Table 1). Koellikerina bouilloni is thought to occur mainly in tropical waters, because 40 specimens have been collected from Laing Island, Papua New Guinea ( $>25^{\circ} \mathrm{C}$ throughout the year) (Bouillon, 1980; Bouillon et al., 1986), whereas only one specimen has been collected from 
Tanabe Bay, Japan, $\left(24^{\circ} \mathrm{C}\right.$ on 22 October 2001) from hundreds of hauls of a plankton net from 1992 to 2005. Therefore, we concluded that the habitat of K. bouilloni differs from that of Koellikerina sp.

\section{Acknowledgements}

We are grateful to Dr. S. Ohtsuka, Captain A. Gou, and the crews of T/RV Toyoshio-maru of the Faculty of Applied Biological Science, Hiroshima University, and Captain Y. Yamamoto and Mr. K. Okita, the crew of T/RV Janthina III of Seto Marine Biological Laboratory, Kyoto University, for their assistance in collecting specimens. We also extend thanks to Dr. S. Ueno, National Fisheries University, for the loan of the plankton net, to Drs. J. Bouillon, C. Massin, and M. Sinon, Royal Belgian Institute of Natural Sciences, for the loan of the specimens, and to two anonymous reviewers for helpful comments.

\section{References}

Bouillon, J. 1980. Hydroméduses de la Mer de Bismarck (Papouasie Nouvelle-Guinée). Partie III: AnthomédusaeFilifera (Hydrozoa-Cnidaria) (1). Cahiers de Biologie marine, 21, 307-344.

Bouillon, J. and Boero, F. 2000. Synopsis of the families and genera of the hydromedusae of the world, with a list of the worldwide species. Thalassia Salentina, 24, 47-296.

Bouillon, J., Claereboudt, M. and Seghers, G. 1986. Hydroméduses de la baie de Hansa (Mer de Bismarck; Papouasie Nouvelle-Guinée). Repartition, conditions climatiques et hydrologiques. Indo-Malayan Zoology, 3, 105-152.

Browne, E. T. 1910. Coelentera. V. Medusae. National Antarctic Expedition 1901-1904, Natural History, Vol. 5 , Zoology and Botany, 1-62, pls.1-7.

Kramp, P. L. 1928. Papers from Dr. Th. Mortensen's Pacific Expedition 1914-16. XLIII. Hydromedusae. I. Anthomedusae. Videnskabelige Meddelelser fra Dansk Naturhistorisk Forening i København, 85, 27-64.

Kramp, P. L. 1939. Occasional Notes on Coelenterata. III. Videnskabelige Meddelelser fra Dansk Naturhistorisk Forening i København, 103, 503-516.

Kramp, P. L. 1948. Trachymedusae and Narcomedusae from the "Michael Sars" North Atlantic deep-sea expedition 1910 with additions on Anthomedusae, Leptomedusae and Scyphomedusae. Report on the Scientific Results of the "Michael Sars" North Atlantic Deep-Sea Expedition 1910, 5 (9), 1-24, pl. 1.

Kramp, P. L. 1959a. The hydromedusae of the Atlantic Ocean and adjacent waters. Dana-Report, 46, 1-283.

Kramp, P. L. 1959b. Some new and little-known Indo-Pacific medusae. Videnskabelige Meddelelser fra Dansk Naturhistorisk Forening i København, 121, 223-259.

Kramp, P. L. 1961. Synopsis of the medusae of the world. Journal of the marine biological Association of the United Kingdom, 40, 7-469.

Kramp, P. L. 1965. The Hydromedusae of the Pacific and Indian Oceans. Dana-Report, 63, 1-162.

Kramp, P. L. 1968. The Hydromedusae of the Pacific and Indian Oceans. Sections II and III. Dana-Report, 72, 1200.

Kubota, S. 1993. The medusa of Thecocodium quadratum (Werner) (Anthomedusae, Ptilocodiidae) from southern Japan. Publications of the Seto Marine Biological Laboratory, 36 (1/2), 89-92.

Kubota, S. 2003. A checklist of the Medusozoa and Ctenophora recorded in Tanabe Bay and its vicinities, Wakayama Prefecture, Japan - connection of polyp and medusa, if present, in the life history. Annual Report of the Seto Marine Biological Laboratory, 16, 30-35. [In Japanese with English abstract]

Kubota, S. 2006. Hydromedusan fauna of the Nansei Islands. In Proceedings of the $10^{\text {th }}$ ICRS, Okinawa. [In Press]. Maas, O. 1905. Die Craspedoten Medusen der Siboga-Expedition. Siboga-Expeditie, 10, 1-84, pls. 1-14.

Mayer, A. G. 1900. Some medusae from Tortugas, Florida. Bulletin of the Museum of Comparative Zoology, 37 (2), 13-82, pls.1-44.

Mayer, A.G. 1910. Medusae of the world. Carnegie Institution of Washington, Washington, D. C., 735 pp., pls. 176.

Menon, M. G. K. 1932. The Hydromedusae of Madras. Bulletin of the Madras Government Museum, New SeriesNatural History Section, 3 (2), 1-33, pls. 1-3.

Miyake, H., Lindsay, D. J. and Kubota, S. 2004. Midwater and bentho-pelagic animals on the south slope of Shiribeshi Seamount off the west coast of Hokkaido. JAMSTEC Journal of Deep Sea Research, 24, 37-42. [In Japanese with English abstract] 
Pagès, F., Gili, J. M. and Bouillon, J. 1992. Medusae (Hydrozoa, Scyphozoa, Cubozoa) of the Benguela Current (southeastern Atlantic). Scientia Marina, 56 (Supplement 1), 1 -64.

Péron, F and Lesueur, C. A. 1810. Tableau des caractères génériques et spécifiques de toutes les espèces de Méduses connues jusqu'à ce jour. Annales du Muséum d'Histoire naturelle, 14, 325-366.

Petersen, K. W. and Vannucci, M. 1960. The life cycle of Koellikerina fasciculata (Anthomedusae, Bougainvilliidae). Pubblicazioni della Stazione Zoologica di Napoli, 31, 473-492.

Schuchert, P. 1996. The marine fauna of New Zealand: Athecate hydroids and their medusae (Cnidaria: Hydrozoa). New Zealand Oceanographic Institute Memoir, 106, 5-159.

$\mathrm{Xu}, \mathrm{Z}$. and Zhang, J. 1978. On the hydromedusae, siphonophores and scyphomedusae from the coast of the east Guangdong Province and South Fujian Province, China. Acta Scientiarum Naturalium Universitatis Amoiensis, 17 (4), 19-63. [In Chinese with English abstract]

$\mathrm{Xu}, \mathrm{Z}$. and Zhang, J. 1981. On the hydromedusae from the continental shelf waters of northern part in the South China Sea. Acta Scientiarum Naturalium Universitatis Amoiensis, 20 (3), 373-382. [In Chinese with English abstract]

$\mathrm{Xu}, \mathrm{Z}$. and Huang, J. 2004. A survey on Anthomedusae (Hydrozoa: Hydroidomedusae) from the Taiwan Strait with description of new species and new combinations. Acta Oceanologica Sinica, 23 (3), 549-562. 